Original Research Article

\title{
Effect of Amomum subulatum seeds against cypermethrin induced haematological changes in wistar albino rats
}

\author{
Goutham Sagarkatte Puttanna ${ }^{1}$, Purushotham K. ${ }^{2 *}$, Swarnalatha Nayak ${ }^{3}$, \\ Eesha B. Rao ${ }^{4}$, Ravi Mundugaru ${ }^{4}$
}

${ }^{1}$ Department of Agada Tantra, SDM College of Ayurveda, Kuthpady, Udupi, Karnataka, India

${ }^{2}$ Department of Pharmacology, Chamarajanagar Institute of Medical Sciences, Yadapura, Karnataka, India

${ }^{3}$ Department of Agada Tantra, SDM College of Ayurveda, Hassan, Karnataka, India ${ }^{4}$ Deptartment of Pharmacology, Kodagu Institute of Medical Sciences, Madikeri, Karnataka, India

Received: 02 February 2019

Accepted: 11 February 2019

\section{*Correspondence to:}

Dr. Purushotham K.,

Email: dr.arian18@gmail.com

Copyright: (C) the author(s), publisher and licensee Medip Academy. This is an openaccess article distributed under the terms of the Creative Commons Attribution NonCommercial License, which permits unrestricted noncommercial use, distribution, and reproduction in any medium, provided the original work is properly cited.

\begin{abstract}
Background: Cypermethrin is a well know agricultural pesticide used in the developing countries. It is associated with significant toxic potential on human health. Hence the present study was aimed to evaluate the protective role of Amomum subulatum against cypermethrin induced haematalogical changes in Wistar albino rats.

Methods: The albino rats were divided into five different groups of six rats each. Group I considered as normal control, group II cypermethrin control $(25 \mathrm{mg} / \mathrm{kg}$ body weight p.o.), group III only test drug and group IV and V administered with cypermethrin $25 \mathrm{mg} / \mathrm{kg}$ body weight along test drug 1.08 and $2.16 \mathrm{mg} / \mathrm{kg}$ body weight for 28 consecutive days. At the end of 28 th day blood was withdrawn and total haematalogical parameters were estimated.

Results: In the cypermethrin control there was significant reduction in the WBC, Platelet, $\mathrm{MCHC}$ and considerable reduction in the haemoglobulin concentration in comparison to normal control. The test drug administered at both dose levels was significantly reversed the cypermethrin induced changes in haematalogical parameters.

Conclusions: Authors can conclude that the Amomum subulatum has potency to reverse the cypermethrin induced haematalogical changes.
\end{abstract}

Keywords: Amomum subulatum, Cypermethrin, Haemoglobulin, Platelet

\section{INTRODUCTION}

Pesticides are the compounds that are used to kill pests which may be insects, rodents, fungi, ticks etc. ${ }^{1}$ India being the second largest producer of fruits and vegetables in the world, farmers being ignorant and the use harmful pesticides like cypermethrin, malathion, aldrin, lindane, endosulfan were still continued. ${ }^{2}$

Over the last few decades agricultural pesticides have become a common household item in rural areas of the developing world. Due to their easy availability, pesticides 
have also become commonly used for intentional selfpoisoning. According to World Health Organization (WHO) estimates around 3 million poisoning cases with 220,000 deaths occur annually. About $99 \%$ of these deaths occur in developing countries. ${ }^{3}$

Cypermethrin is a pyrethroid insecticide. It was first synthesized in 1974. It is known to act as both a stomach and a contact poison. Its selective toxic effects are related to the neural sodium channels. The metabolism of cypermethrin is quite rapid, and during its metabolism reactive oxygen species (ROS) are generated. These free radicals, which are most active, cause oxidative stress through peroxidation of the lipid membrane. Damage may occur in certain tissues and organs, due to either the free radicals that are generated or the direct effect of the pesticide. $^{4}$

Bruhat Ela (Amomum subulatum), commonly known as large cardamom, is a perennial herbaceous plant native to Sikkim and from there it spreads to neighboring areas like Darjeeling, Assam, Bhutan and Nepal. ${ }^{5}$ The fruits are prescribed to treat indigestion, vomiting, biliousness, abdominal pains, rectal diseases, throat troubles, congestion of the lungs, inflammation of the eye lids, digestive disorder, pulmonary tuberculosis, loss of appetite, gastric troubles, liver complaints and also used as diuretics. ${ }^{6}$

The phytochemical analysis of Amomum subulatum seeds shown the following chemicals compositions such as protocatechualdehyde, protocatechuic acid, 1,7-bis $(3,4-$ dihydroxyphenyl)hepta-4E, 6E-dien-3-one and 2,3,7trihydroxy-5-(3,4-dihydroxy-E-styryl)-6,7,8,9-tetra hydro-5H-benzocyc loheptene. 7 It has been reported to possess different pharmacological actions such as its gastroprotective, anti-diabetic, hepatoprotective, fibrinolytic, lipid lowering, and antioxidant enhancing effects. $^{8-11}$

The present study was aimed to evaluate the protective effect of Bruhat Ela on hematological changes induced by repeated exposure of cypermethrin.

\section{METHODS}

\section{Plant material}

The large cardamom (Amomum subulatum) was collected from SDM Pharmacy at Udupi, India and authenticated by Pharmacognosy department at SDM Centre for Research in Ayurveda \& Allied Sciences, Udupi.

A voucher specimen (No. 199/ 12121701) had been deposited for further future reference. The Seeds of greater cardamom were removed from the pod and the seeds were powdered. The powder was sieved using sieve no. 100 and stored in a clean and dry air tight container. The powder obtained from a single batch was used throughout the study.

\section{Experimental animals}

Male wistar albino rats of weight $200 \pm 50 \mathrm{~g}$ body weight were procured from animal house attached to Pharmacology laboratory at SDM Research Centre Udupi. Animals were maintained at standards laboratory conditions such as temperature at $25 \pm 2^{\circ} \mathrm{C}$, humidity of 55$60 \%$ and natural day and night cycle. They were fed with Amrut brand rat pellet feed supplied by Sri Durgha feeds Bangalore and tap water given ad libitum. The study protocol was approved from Institutional animal ethical committee (SDMCRA/IAEC-2012-13, HSN-22) and principles of laboratory animal care guidelines were followed throughout the experimentation.

\section{Dose fixation}

The dose of Bruhat Ela for the purpose of cytoprotective action in human was $12 \mathrm{~g} .{ }^{12}$ The dose for rats was calculated based on body surface area ratio by referring to the standard table of Paget et al. ${ }^{13}$ Based on this the rat dose was found to be $1.08 \mathrm{~g} / \mathrm{kg}$. The test drug was suspended in distilled water with suitable concentration depending upon body weight of animals ( $1 \mathrm{ml} / 100 \mathrm{~g}$ body weight) and administered by oral catheter.

\section{Chemicals}

Cypermethrin Batch No.-005 MFG.-March-2014 EXP.Feb 2016 manufactured in India by Contropest, Dodden Kunal Industrial Area, Whitefield, Bengaluru.

\section{Experimental design}

Male albino rats weighing 150 to $200 \mathrm{~g}$ body weight were divided into five different groups of six animals each. Group -I was administered with normal tap water at a dose of $5 \mathrm{ml} / \mathrm{kg}$ and considered as normal control group. Group II administered with cypermethrin $(25 \mathrm{mg} / \mathrm{kg})$ and served as toxic control. ${ }^{14}$ Group III administered with Bruhat Ela $(1.08 \mathrm{mg} / \mathrm{kg})$. Group IV and V administered with Bruhat Ela at a dose of 1.08 and $2.16 \mathrm{~g} / \mathrm{kg}$ bodyweight along with cypermethrin $25 \mathrm{mg} / \mathrm{kg}$. The group specific drugs were administered once daily for 28 days consecutive days. On $28^{\text {th }}$ day an hour after last dosage, blood was withdrawn from retro-orbital plexus and haematalogical parameters were estimated using hematology analyzer.

\section{RESULTS}

\section{Haematology}

Repeated administration of cypermethrin resulted in significant reduction in $\mathrm{WBC}$, platelet, $\mathrm{MCHC}$ and nonsignificant reduction in the hemoglobin concentration as compared to control group. Test drug only administered group has shown significant increase in the hemoglobin, WBC and RDWCV concentration as compared to control group. Whereas the test drug administered at both therapeutic and doubles the therapeutic dose has been 
significantly reversed cypermethrin induced toxicity. The parameters such as RBC, RDWSD, MCHC, MCV and
$\mathrm{MCH}$ were normal and values were comparable with that of control group (Table 1).

Table 1: Effect of test drug on haematalogical parameters.

\begin{tabular}{|llllllllll|}
\hline Hb\% & RBC & WBC & MCH & MCHC & PCV & MCV & $\begin{array}{l}\text { RDW- } \\
\text { CV }\end{array}$ & $\begin{array}{l}\text { RDW-SD } \\
\text { Platelet } \\
\text { count }\end{array}$ \\
\hline \multirow{2}{*}{$14.43 \pm 0.32$} & $7.431 \pm$ & $8200 \pm$ & $19.43 \pm$ & $36.35 \pm$ & $39.63 \pm$ & $53.53 \pm$ & $14.45 \pm$ & $27.816 \pm$ & $8.028 \pm$ \\
& 0.2328 & 333.67 & 0.3870 & 0.1310 & 0.823 & 1.026 & 0.6515 & 0.4651 & 0.392 \\
\hline \multirow{2}{*}{$12.9 \pm 1.24$} & $6.513 \pm$ & $3280 \pm$ & $19.78 \pm$ & $33.53 \pm$ & $38.35 \pm$ & $59.08 \pm$ & $14.86 \pm$ & $31.03 \pm$ & $5.343 \pm$ \\
& 0.6185 & $383.93 \#$ & 0.5913 & $0.316 @$ & 3.628 & 1.672 & 0.3913 & 0.9722 & $1.18 @$ \\
\hline \multirow{2}{*}{$15.93 \pm 0.44^{\#}$} & $8 \pm$ & $16166.6 \pm$ & $19.9 \pm$ & $34.96 \pm$ & $45.48 \pm$ & $57.2 \pm$ & $18.6 \pm$ & $34.83 \pm$ & $6.188 \pm$ \\
& 0.2952 & $1586.3^{\# \#}$ & 0.3606 & 0.4609 & 0.9163 & 1.748 & $1.441^{*}$ & 2.932 & 0.244 \\
\hline \multirow{2}{*}{$15.2 \pm 0.40$} & $7.59 \pm$ & $5200 \pm$ & $20 \pm$ & $33.36 \pm$ & $45.68 \pm$ & $60.2 \pm$ & $14.96 \pm$ & $31.86 \pm$ & $8.481 \pm$ \\
& 0.2510 & 443.47 & 0.1633 & 0.7260 & $2.021 *$ & 0.9957 & 0.3870 & 0.9146 & $0.343^{\#}$ \\
\hline \multirow{2}{*}{$14.76 \pm 0.62$} & $7.111 \pm$ & $13866.6 \pm$ & $21.033 \pm$ & $33.36 \pm$ & $44.15 \pm$ & $63.88 \pm$ & $17.5 \pm$ & $37.83 \pm$ & $7.075 \pm$ \\
& 0.5387 & $1533.3^{\# \#}$ & 0.9841 & 1.048 & 0.8609 & 4.891 & 1.408 & 5.240 & 0.44 \\
\hline
\end{tabular}

Data expressed in Mean \pm SEM, *p<0.05, **p<0.01, @ -in comparison to normal control group, \# in comparison to cypermethrin control.

\section{DISCUSSION}

The observed changes can be categorized in to those showing significant deviation from the normal values, those showing moderate deviation from the control but not of sufficient intensity to attain statistically significant level and those which showed only a mild or no deviation from the normal control values. Ten hematological parameters studied, three parameters were found to be significantly altered in cypermethrin control in comparison to normal control. The changes were significant decrease in WBC total count, MCHC and platelet count. Other parameters were not affected to significant extent. Though moderate changes were observed in RBC count, RDW-SD, PCV and $\mathrm{MCV}$ - they were not of much significance. Interestingly, $\mathrm{Hb}$ percentage was found to be elevated in Amomum subulatum alone given group- this is in contrast to nonsignificant decrease observed in cypermethrin control group. This weak effect of the toxicant was found to be reversed in non-significant manner by TED x 2 dose of the Ela. RBC count was found to be non-significantly decreased by the toxicant which was reversed in nonsignificant manner in both the test drug administered group. The exact reason for the modest decrease observed in the above two parameters is not known. It may be due to decreased formation or increased breakdown. The activity profile may be taken to represent protection offered by the test drug against the toxicant's effects on the above parameters.

The possible reason for WBC count is higher mobilization to the site of inflammation or less production due to effect on the stem cell in the bone marrow. Another possibility is that the toxicant may be down regulating the formation of the concerned growth factor responsible for the formation of WBC. ${ }^{15}$ This toxicant effect was reversed by the test drug treatment especially at higher dose level- indicating protection against the deleterious effects of the toxicant.

Decrease in MCHC is indicative of iron-deficiency either due to insufficient absorption or increased blood loss. Cypermethrin is known to have hemolytic effect. Hence, it may be the reason for the observed moderate but significant decrease in MCHC. This was not reversed to significant extent. $^{16}$

The third significant hematological effect produced by the toxicant is the decrease in platelet count. This may be due to reduced formation of thrombopoietin which regulates platelet formation. This toxicant effect was also significantly reversed by the test drug though not in dose dependent fashion. Thus, based on the changes produced in the hematological parameters it can be suggested that test drug has significant reversal effect on the toxicant induced changes in hematological parameters.

\section{CONCLUSION}

Repeated exposure of cypermethrin caused toxic changes in the haematalogical parameters and these changes were significantly reversed by Amomum subulatum at higher dose level. Thus, authors can conclude that the test drug has protective role in the cypermethrin induced toxicity.

\section{ACKNOWLEDGEMENTS}

Authors are highly grateful to the President, Dr. D. Veerendra Heggade for the constant support, Dr. B. Yashoverma, Secretary, SDM Educational Society for the guidance and Director and head of Experimental Medicine SDM Centre for Research in Ayurveda and Allied Sciences Udupi, Karnataka, India. 
Funding: No funding sources

Conflict of interest: None declared

Ethical approval: The study was approved by the Institutional Ethics Committee

\section{REFERENCES}

1. Sharma P, Huq AU, Singh R. Cypermethrin-induced reproductive toxicity in the rat is prevented by resveratrol. J Hum Reprod Sci. 2014 Apr;7(2):99.

2. Srinivas Rao $\mathrm{CH}$, Venkateswarlu V, Surender $\mathrm{T}$, Eddleston M, Buckley NA. Pesticide poisoning in south India: opportunities for prevention and improved medical management. Trop Med Int Health. 2005 Jun;10(6):581-8.

3. Aktar W, Sengupta D, Chowdhury A. Impact of pesticides use in agriculture: their benefits and hazards. Interdisciplinary Toxicol. 2009 Mar 1;2(1):12.

4. Ahme AM, Naqvi SNH, Akhtar K, Moinuddin, Parveen S. Effect of pesticide residues on health and blood parameters of farm workers from rural Gadap. J Environment Biol. 2009;30(5):747-56.

5. Sharma E, Sharma R, Singh KK, Sharma G. A boon for mountain populations: Large cardamom farming in the Sikkim Himalaya. Mountain Res Developent. 2000 May;20(2):108-11.

6. Gupta PN. Studies on capsule morphology of large cardamom cultivars (Amomum subulatum Roxb), J. Plantation Crops. 1986;16:371-5.

7. Shukla SH, Mistry HA, Patel VG, Jogi BV. Pharmacognostical, preliminary phytochemical studies and analgesic activity of Amomum subulatum Roxb. Pharma Sci Monitor. 2010;1(1):90-102.

8. Jafri MA, Javed K, Singh S. Evaluation of the gastric antiulcerogenic effect of large cardamom (fruits of Amomum subulatum Roxb). J Ethnopharmacol. 2001 May 1;75(2-3):89-94.

9. Verma SK, Rajeevan V, Bordia A, Jain V. Greater cardamom (Amomum subulatum Roxb.): A cardio- adaptogen against physical stress. J Herb Med Toxicol. 2010;4(2):55-8.

10. Vavaiya RB, Patel A, Manek RA. Anti-diabetic activity of Amomum subulatum Roxb. fruit constituents. IJPI. 2010;2(5):50-63.

11. Bhatti GK, Sidhu IP, Saini NK, Puar SK, Singh G, Bhatti JS. Ameliorative role of melatonin against cypermethrin induced hepatotoxicity and impaired antioxidant defense system in Wistar rats. IOSR J Environment Sci Toxicol Food Technol. 2014 Feb;8(1):39-48.

12. Chatterjee A, Pakrashi SC. Treaties on Indian medicinal plants: National Institute of Science Communication and information resources, New Delhi, India. 2003;3:146-7,149.

13. Paget GE, Barnes JM. Evaluation of drug activities. In: Lawrence DR, Bacharach AL, editors. Pharmacometrics. New York; Academic press $161 ; 1964$.

14. Adjrah Y, Karou SD, Agbonon A, Ameyapoh Y, Gbeassor M. Effect of cypermethrin-treated lettuce (Lactuca sativa) on wistar rat liver. J App Pharmaceut Sci. 2013 Jan 1;3(1):128.

15. Buckley CD, Barone F, Nayar S, Benezech C, Caamano J. Stromal cells in chronic inflammation and tertiary lymphoid organ formation. Ann Rev Immunol. 2015 Mar 21;33:715-45.

16. Nair H, Nokes DJ, Gessner BD, Dherani M, Madhi SA, Singleton RJ, et al. Global burden of acute lower respiratory infections due to respiratory syncytial virus in young children: a systematic review and metaanalysis. Lancet. 2010 May 1;375(9725):1545-55.

Cite this article as: Puttanna GS, Purushotham K, Nayak S, Rao EB, Mundugaru R. Effect of Amomum subulatum seeds against cypermethrin induced haematological changes in wistar albino rats. Int $\mathbf{J}$ Basic Clin Pharmacol 2019;8:604-7. 